\title{
Relationship between soil fungal diversity and temperature in the maritime Antarctic
}

\author{
Published online as a letter by MacMillan Publishers in Nature Climate Change on $28^{\text {th }}$ \\ September 2015
}

DOI: 10.1038/NCLIMATE2806

Kevin K. Newsham ${ }^{1,2}$, David W. Hopkins ${ }^{3}$, Lilia C. Carvalhais ${ }^{4}$, Peter T. Fretwell ${ }^{1}$, Steven P. Rushton $^{5}$, Anthony G. O'Donnell ${ }^{6}$ and Paul G. Dennis ${ }^{4^{*}}$

${ }^{1}$ NERC British Antarctic Survey, Madingley Road, Cambridge, CB3 OET, UK, ${ }^{2}$ Department of Arctic Biology, the University Centre in Svalbard, P.O. Box 156, N-9171 Longyearbyen, Svalbard, ${ }^{3}$ The Royal Agricultural University, Cirencester, Gloucestershire, GL7 6JS, UK. ${ }^{4}$ School of Agriculture and Food Sciences, The University of Queensland, Brisbane, QLD 4072, Australia, 5 School of Biology, Newcastle University, Newcastle upon Tyne, NE1 7RU, UK, ${ }^{6}$ University of Western Australia, 35 Stirling Highway, Crawley, WA 6009, Australia. *e-mail: p.dennis@uq.edu.au.

Soil fungi have pivotal ecological roles as decomposers, pathogens and symbionts ${ }^{1,2}$. Alterations to their diversity arising from climate change could thus have substantial effects on ecosystems, particularly those undergoing rapid warming that contain few species ${ }^{3,4}$. Here, we report a study using pyrosequencing to assess fungal diversity in 29 soils sampled from along a 1,650 km climatic gradient through the maritime Antarctic, the most rapidly-warming region in the southern hemisphere ${ }^{5,6}$. Using a 'space-for-time' substitution approach, we show that soil fungal diversity is higher in warmer habitats, with increases of 4.7 (observed) and 11.3 (predicted) fungal taxa per degree Celsius rise in surface air temperature along the transect. Among 22 measured predictor variables, air temperature was the most consistent and strongest predictor of diversity. We propose that the current rapid warming in the maritime Antarctic $\left(0.34^{\circ} \mathrm{C}\right.$ per decade $\left.{ }^{6}\right)$ will facilitate the colonization of soil by a wider diversity of fungi than at present, with data from regression models suggesting $20-27 \%$ increases in soil fungal species richness in the southernmost soils by 2100 . Such increases in diversity, which provide a sentinel for changes at lower latitudes, are likely to have substantial impacts on nutrient cycling and, ultimately, net productivity in the species-poor soils of maritime Antarctica.

The maritime Antarctic is undergoing rapid climate change. Surface air temperatures in the region, which broadly encompasses the Antarctic Peninsula and islands of the Scotia Arc, have risen by up to $2.8^{\circ} \mathrm{C}$ over the last 50 years, at rates several times that of the global mean ${ }^{5,6}$. Rising temperatures in the region have led to changes to the physical environment, including ice shelf collapses and glacier retreats ${ }^{5}$. However, in recent years, biological responses to warming have also become apparent 
across the region ${ }^{7}$. These include order of magnitude increases in the population sizes of the two native angiosperms, increased moss growth rates, and the establishment of non-native plant species $^{8-10}$. The range expansions of native plant populations and the establishment of non-native species in the typically unvegetated soils of the region are thought to be associated with new areas of land becoming exposed following glacial retreat, enhanced plant growth and reproduction, and accelerated soil nutrient cycling ${ }^{7,10,11}$.

Although climate change effects on the maritime Antarctic flora have recently become apparent, far less is known of soil microbial responses to warming in the region. Artificial warming experiments in the natural environment have shown relatively minor changes to the composition of bacterial communities in response to increased soil temperatures $\left(0.5-2{ }^{\circ} \mathrm{C}\right.$ annual means), which is not surprising as the experiments have only lasted for one to three years ${ }^{12,13}$. However, the responses of soil fungi to climate warming in the maritime Antarctic have yet to receive attention. Despite their pivotal importance in terrestrial ecosystems as decomposers, pathogens and symbionts ${ }^{1,2}$, the majority of fungi are filamentous in form and grow slowly in the natural environment ${ }^{14}$, hampering assessments of their responses to warming treatments. For instance, in the low Arctic, substantial changes to root symbiotic fungal communities in response to warming only become apparent after 17 years of treatment $t^{15}$. Here, in order to circumvent the problem of detecting the responses of these slow-growing microbes to warming manipulations, we studied fungi in soil sampled from along a natural climatic gradient through the maritime Antarctic. Using a similar approach to previous 'spacefor-time' substitution studies ${ }^{16,17}$, we employ the gradient as a proxy to predict changes to soil fungal communities arising from climate warming in the region. We show that surface air temperature is a significant factor shaping the diversity and composition of soil fungal communities. On the basis of our observations, we predict that future warming in the region will lead to $20-27 \%$ increases in the numbers of fungal species present in the southernmost soils of the region by the end of the century, and that this will have consequent effects on biological productivity.

We studied 29 soils sampled during the 2007-2008 austral spring and summer from along a $1,650 \mathrm{~km}$ gradient between $72^{\circ} \mathrm{S}$ and $60^{\circ} \mathrm{S}$ (Fig. 1; Supplementary Table S1). The soils were free of vegetation (Supplementary Fig. S1), and were hence representative of the barren soils that are frequent in maritime Antarctic terrestrial ecosystems. Data from the Regional Atmospheric Climate Mode ${ }^{18}$ indicated a significant increase in mean annual surface air temperature (MASAT) between south-eastern Alexander Island $\left(72^{\circ} \mathrm{S}\right.$; MASAT $\left.-11^{\circ} \mathrm{C}\right)$ and Signy Island in the South Orkney Islands $\left(60^{\circ} \mathrm{S}\right.$; MASAT $\left.-4{ }^{\circ} \mathrm{C}\right)$, with a $0.62{ }^{\circ} \mathrm{C}$ increase in air temperature for each degree decrease in latitude (Fig. 1, upper inset; Supplementary Table S2). To determine whether other abiotic parameters altered along the transect, we analysed soils for a suite of 20 physicochemical parameters (including $\mathrm{pH}$, electrical conductivity and the concentrations of 11 elements and five dissolved ions). Soil C:N ratio declined significantly at lower latitudes $\left(R^{2}=33 \%, P=0.001\right.$; Fig. 1, lower inset; Supplementary Table S2) and was negatively associated with MASAT $\left(R^{2}=31 \%, P=0.002\right)$. This is consistent with previous observations that soils in cold ecosystems have higher $\mathrm{C}: \mathrm{N}$ ratios than those in warmer ecosystems ${ }^{19}$, most likely because of slow organic matter decay ${ }^{1}$. The strong influence of latitude on MASAT, and its weaker effect on soil C:N ratio, were also confirmed by structural equation modelling (Supplementary 
Fig. S2). None of the other parameters that we measured, including the altitude from which the samples were taken, altered significantly with latitude (Supplementary Table S2).

We measured the numbers of fungal species present in soil along the climatic gradient by PCR amplifying and pyrosequencing internal transcribed spacer 2 regions of fungal ribosomal RNA operons. Each fungal taxon was represented by an operational taxonomic unit (OTU), which differed by $>3 \%$ in sequence identity from other OTUs. In contrast with studies on other continents, where woody plant species are present and ectomycorrhiza-forming basidiomycetes are consequently frequent in soil ${ }^{2}$, we found relatively few basidiomycetes, with ascomycetes dominating the soil fungal communities (Supplementary Fig. S3). When stepwise multiple regression analyses were used to assess how the numbers of observed and predicted (Chao 1) OTUs responded to the 21 predictors along the gradient, MASAT was consistently the best predictor for both measures of soil fungal diversity (Table 1), explaining $23 \%$ and $39 \%$ of variation in the numbers of observed and predicted OTUs, respectively. Univariate regression analyses indicated significant positive associations between MASAT and the numbers of fungal OTUs, with mean increases of 4.7 observed OTUs and 11.3 predicted OTUs per degree Celsius rise in air temperature along the transect (Fig. 2a, b). Soil potassium $(\mathrm{K})$ concentration, which is known to be positively associated with the frequencies of fungi ${ }^{20}$, was also included in stepwise regression models, and explained $12-14 \%$ of variation in the numbers of OTUs (Table 1). C:N ratio, also previously shown to influence soil fungal abundances ${ }^{2,20}$, explained a small (4.3\%) but significant amount of variation in the predicted number of OTUs (Table 1).

Redundancy analysis (RDA) was then used to determine how the frequencies of the fungal OTUs varied with the 22 predictors across the gradient. These analyses indicated that changes to soil fungal community composition were best predicted by MASAT $\left(R^{2}=6.1 \%, P<0.001\right)$, with soil $\mathrm{pH}$, manganese $(\mathrm{Mn})$ concentration and $\mathrm{C}: \mathrm{N}$ ratio predicting significant, but smaller, amounts of variation in composition $\left(R^{2}=4.8 \%-3.8 \%\right.$, all $\left.P<0.03\right)$. MASAT was the best predictor for three OTUs closely matching mycobionts of the lichen genus Verrucaria or the family Verrucariaceae (Supplementary Fig. S3), which each increased in frequency in warmer soils (Fig. 3a-c). Verrucaria is typically a rockinhabiting genus in the Antarctic ${ }^{21}$ and it is hence likely that we detected the fungus in its free-living state (or as spores or other propagules) in soil. RDA based on presence-absence data indicated that changes to the frequencies of Verrucaria largely accounted for the increase in fungal diversity in warmer soils, corroborating the previous observation that the numbers of maritime Antarctic lichen taxa increase sharply between $72^{\circ} \mathrm{S}$ and $60^{\circ} \mathrm{S}^{22}$. The yeast Rhodotorula and a member of the Helotiales, representatives of which are known to be present in Antarctica (Supplementary Table $\mathrm{S} 3)^{23}$, also accounted for increases in fungal diversity in warmer soils (Fig. 3d, e). In contrast, we found that the frequencies of three other OTUs were best predicted by MASAT (Supplementary Fig. S3), but that these fungi, which matched closely with a Verrucaria, an unclassified ascomycete and Cladosporium, decreased in frequency in warmer soils (Fig. 3f-h). As C:N ratio was associated with air temperature (Fig. 1, lower inset), and there was a priori evidence indicating that this parameter is associated with climate ${ }^{1,19}$, we also included the ratio in the RDA analyses. Soil C:N ratio was found to be positively associated with the abundances of OTUs matching closely with the lichen-forming 
ascomycete Polysporina and the free-living ascomycetes Cladosporium, Pseudoeurotium and Penicillium (Fig. 4a-d; Supplementary Fig. S3), confirming the direct influence of this parameter on soil fungal community composition ${ }^{2,20}$. Associations between OTU frequencies and soil $\mathrm{pH}, \mathrm{K}$ and $\mathrm{Mn}$ concentrations, which influenced soil fungal diversity but did not alter along the gradient, are summarised in Supplementary Fig. S3.

Our observations show that surface air temperature is an important factor shaping the diversity and composition of maritime Antarctic soil fungal communities. Because liquid water availability is tightly coupled with air temperature in maritime Antarctic environments ${ }^{24}$, it is likely that part of the observed pattern of increasing fungal diversity in warmer habitats is owing to improved access to water, which, in combination with higher temperatures, will enhance metabolic activity, extend the period for which fungi are active each year, and enable a switch from survival to growth and dispersal strategies. Our observations thus extend into the Antarctic the recent finding that climate has an important influence on soil fungal diversity on the Earth's other continents ${ }^{2}$. They suggest that declines in soil C:N ratio arising from climate warming in the maritime Antarctic might result in reductions in the frequencies of several ascomycetes in soil, including the widespread saprotrophs Penicillium and Cladosporium, which are known to be of importance in soil decomposition processes ${ }^{1}$. However, the overriding impact of warming is likely to be an increase in the number of fungal taxa present in the soils of the region. The data here indicate that increases are likely in the frequencies of mycobionts of the lichen-forming genus Verrucaria, which are known to influence rock weathering processes, the yeast genus Rhodotorula, and the order Helotiales, some members of which positively affect the in vitro growth of the angiosperms spreading throughout the region ${ }^{25}$.

The rate at which fungal diversity will increase in maritime Antarctic soils will be influenced not only by rising air temperatures but also by precipitation, which is likely to increase as the region warms $^{6}$, and by vectors such as air currents and human activities, including tourism ${ }^{9}$. However, assuming a current rate of warming over land in the maritime Antarctic of $0.34{ }^{\circ} \mathrm{C}$ per decade ${ }^{6}$, and increases of 4.7 observed species of soil fungi per degree Celsius rise in air temperature, our analyses (Table 1) suggest up to a $20 \%$ increase in the numbers of fungal species present in the southernmost soils of the region by 2100 . The estimates for the predicted numbers of fungal species are similar, with multiple regression models - taking into account both increases in air temperature and decreases in soil C: $\mathrm{N}$ ratio (Table 1 ) - indicating a $27 \%$ rise in the numbers of species currently present in soils at the highest latitudes by the end of the century. Given the pivotal roles of soil fungi as decomposers, symbionts and pathogens $s^{1,2,20,26}$ and the demonstrable positive effects of increasing soil fungal diversity on productivity in species-poor soils ${ }^{3,4}$, our data suggest substantial impacts of such increases on the ecology of maritime Antarctic terrestrial ecosystems, and on other low diversity soil fungal communities at lower latitudes.

\section{Acknowledgements}

Logistical support was provided by the British Antarctic Survey and the Royal Navy (HMS Endurance). Vito Armando Laudicina, Victoria Ord, Phil Coates, Mike Dunn, Paul Torode, Matt 
Jobson, Adam Clark, James Wake, Dickie Hall, Gareth Marshall, Magda Biszczuk and Kate Bazeley provided technical support. This work was funded by a UK Natural Environment Research Council Antarctic Funding Initiative grant (NE/D00893X/1; AFI 7/05) led by D.W.H. and a University of Queensland Early Career Researcher Award to P.G.D. All are gratefully acknowledged.

\section{Author contributions}

K.K.N., P.G.D., S.P.R., A.G.O. and D.W.H. conceived this study. P.G.D., K.K.N. and D.W.H. collected soil samples, L.C.C. performed DNA extractions and PCRs. P.G.D. processed sequence data and P.G.D. and K.K.N. performed statistical analyses. P.T.F. provided geospatial data derived from the Regional Atmospheric Climate Model. All authors discussed the results and contributed to the preparation of the manuscript.

\section{Accession codes}

The amplicon sequences associated with this study have been deposited in the NCBI SRA under accession PRJNA282894.

\section{References}

1. Swift, M. J., Heal, O. W. \& Anderson, J. M. Decomposition in Terrestrial Ecosystems (Blackwell Scientific Publications, Oxford, 1979).

2. Tedersoo, L. et al. Global diversity and geography of soil fungi. Science 346, 1078 (2014).

3. Setälä, H. \& McLean, M. A. Decomposition rate of organic substrates in relation to the species diversity of soil saprophytic fungi. Oecologia 139, 98-107 (2004).

4. Tiunov, A. \& Scheu, S. Facilitative interactions rather than resource partitioning drive diversityfunctioning relationships in laboratory fungal communities. Ecol. Lett. 8, 618-625 (2005).

5. Adams, B. et al. in Antarctic Climate Change and the Environment (eds. Turner, J. et al.) 183298 (Scientific Committee on Antarctic Research, Scott Polar Research Institute, 2009).

6. Turner, J. et al. Antarctic climate change and the environment: an update. Polar Rec. 50, 237259 (2014)

7. Convey, P. \& Smith, R. I. L. Responses of terrestrial Antarctic ecosystems to climate change. Plant Ecol. 182, 1-10 (2006).

8. Fowbert, J. A. \& Smith, R. I. L. Rapid population increases in native vascular plants in the Argentine Islands, Antarctic Peninsula. Arctic Alpine Res. 26, 290-296 (1994).

9. Frenot, Y. et al. Biological invasions in the Antarctic: extent, impacts and implications. Biol. Rev. 80, 45-72 (2005).

10. Royles, J. et al. Plants and soil microbes respond to recent warming on the Antarctic Peninsula. Curr. Biol. 23, 1-5 (2013).

11. Hill, P. W. et al. Vascular plant success in a warming Antarctic may be due to efficient nitrogen acquisition. Nature Clim. Change 1, 50-53 (2011).

12. Yergeau, E. et al. Shifts in soil microorganisms in response to warming are consistent across a range of Antarctic environments. ISME Journal 6, 692-702 (2011). 
13. Dennis, P. G. et al. Warming constrains bacterial community responses to nutrient inputs in a southern, but not northern, maritime Antarctic soil. Soil Biol. Biochem. 57, 248-255 (2013).

14. Green, T. G., Brabyn, L., Beard, C. \& Sancho, L. G. Extremely low lichen growth rates in Taylor Valley, Dry Valleys, continental Antarctica. Polar Biol. 35, 535-541 (2012).

15. Deslippe, J. R., Hartmann, M., Mohn, W. W. \& Simard, S. W. Long-term experimental manipulation of climate alters the ectomycorrhizal community of Betula nana in Arctic tundra. Glob. Change Biol. 17, 1625-1636 (2011).

16. Parmesan, C. \& Yohe, G. A globally coherent fingerprint of climate change impacts across natural ecosystems. Nature 421, 37-42 (2003).

17. Bragazza, L., Parisod, J., Buttler, A. \& Bardgett, R. D. Biogeochemical plant-soil microbe feedback in response to climate warming in peatlands. Nature Clim. Change 3, 273-277 (2013).

18. Van Lipzig, N. P. M., Van Meijgaard, E., Oerlemans, J. Evaluation of a regional atmospheric model using measurements of surface heat exchange processes from a site in Antarctica. Mon. Weather Rev. 127, 1994-2011 (1999).

19. Callesen, I., Rauland-Rasmussen, K., Westman, C. J., \& Tau-Strand, L. Nitrogen pools and C:N ratios in well-drained Nordic forest soils related to climate and soil texture. Boreal Environ. Res. 12, 681-692 (2007).

20. Osono, T., Matsuoka, S., Hirose, D., Uchida, M., Kanda, H. Fungal colonization and decomposition of leaves and stems of Salix arctica on deglaciated moraines in high-Arctic Canada. Polar Sci. 8, 207-216 (2014).

21. Øvstedal, D. O. \& Smith, R. I. L. Lichens of Antarctica and South Georgia: a guide to their identification and ecology (Studies in Polar Research, Cambridge University Press, 2001).

22. Peat, H. J., Clarke, A., Convey, P. Diversity and biogeography of the Antarctic flora. J. Biogeogr. 34, 132-146 (2007).

23. Pointing, S. B. et al. Highly specialized microbial diversity in hyper-arid polar desert. Proc. Nat. Acad. Sci. USA 106, 19964-19969 (2009).

24. Green, T. G., Sancho, L. G., Pintado, A. \& Schoeter, B. Functional and spatial pressures on terrestrial vegetation in Antarctica forced by global warming. Polar Biol. 34, 1643-1656 (2011).

25. Upson, R., Newsham, K. K. \& Read, D. J. Nitrogen form influences the response of Deschampsia antarctica to dark septate root endophytes. Mycorrhiza 20, 1-11 (2009).

26. Chan, Y., Van Nostrand, J. D., Zhou, J., Pointing, S. B. \& Farrell, R. L. Functional ecology of an Antarctic Dry Valley. Proc. Nat. Acad. Sci. USA 110, 8990-8995 (2013). 
Table 1 | Data from stepwise multiple regression models using observed and predicted (Chao 1) numbers of OTUs as response variables.

\begin{tabular}{|c|c|c|c|c|c|}
\hline response variable & $R^{2}(\%)$ & predictor variables & slope & $F$ value & $P$ value \\
\hline \multirow[t]{2}{*}{ observed no. OTUs } & 35 & MASAT* & 4.7 & 9.15 & 0.006 \\
\hline & & soil $\mathrm{K}$ concentration & $4.4 \times 10^{-3}$ & 4.83 & 0.037 \\
\hline \multirow[t]{3}{*}{ predicted no. OTUs } & 57 & MASAT* & 14.8 & 24.55 & $<0.001$ \\
\hline & & soil $\mathrm{K}$ concentration & $9.2 \times 10^{-3}$ & 8.12 & 0.009 \\
\hline & & soil C:N ratio & 4.8 & 4.46 & 0.045 \\
\hline
\end{tabular}

*mean annual surface air temperature. Error degrees of freedom in all analyses were 26. MASAT and $\mathrm{K}$ concentration were expressed in degrees Celsius and $\mathrm{mg} \mathrm{kg}^{-1}$ in these analyses, respectively, and $\mathrm{C}: \mathrm{N}$ ratio was dimensionless. Intercepts in multiple regression models for observed and predicted numbers of OTUs were 112 and 199, respectively. 


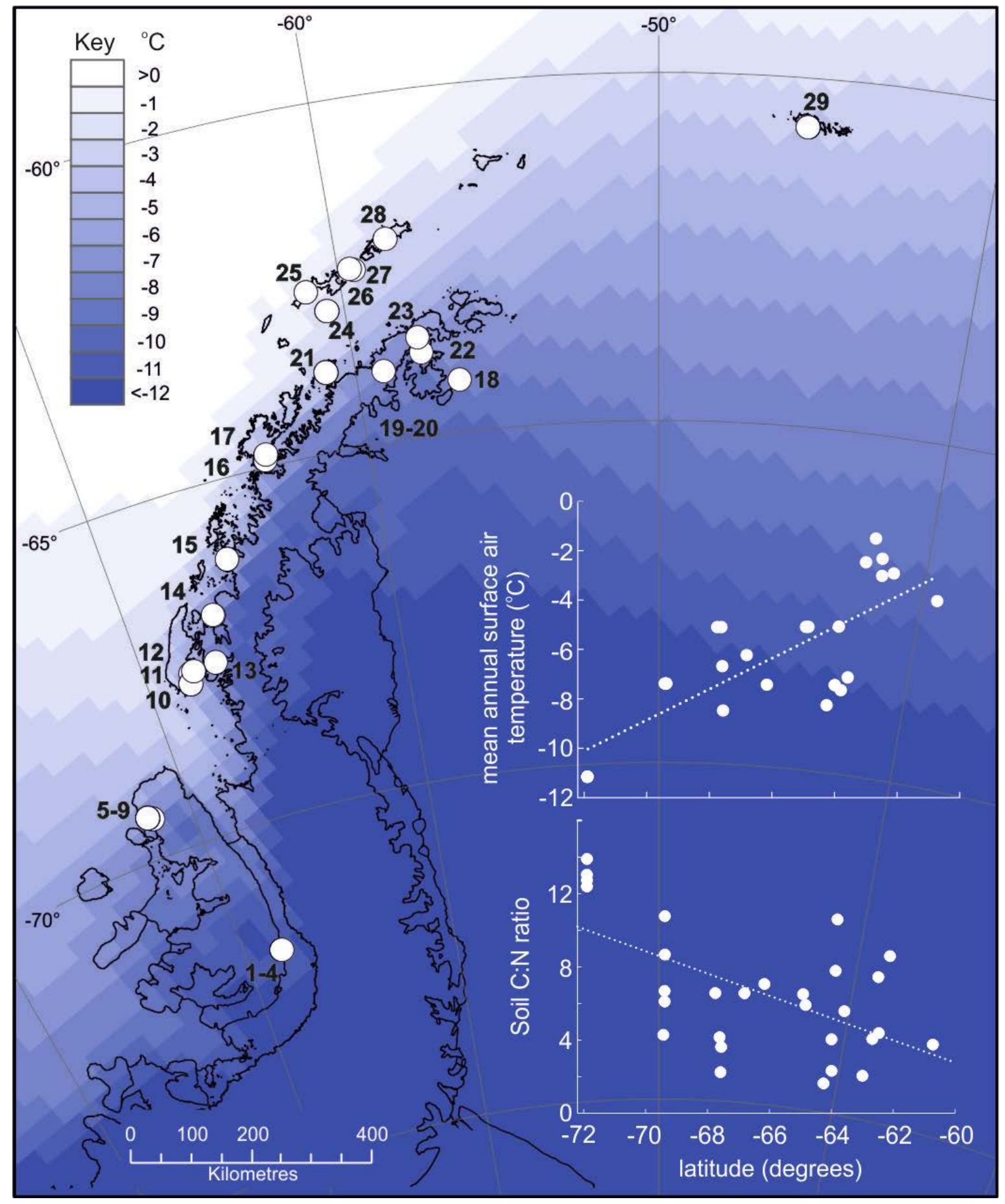

Figure 1 | Locations of sampling sites along the climatic gradient. Site names, latitudes, longitudes and altitudes are shown in Supplementary Table S1. Upper inset shows mean annual surface air temperature at each sampling location for 2007, derived from the Regional Atmospheric Climate Model $^{18}$, as a function of latitude. Lower inset shows soil C:N ratio as a function of latitude. 


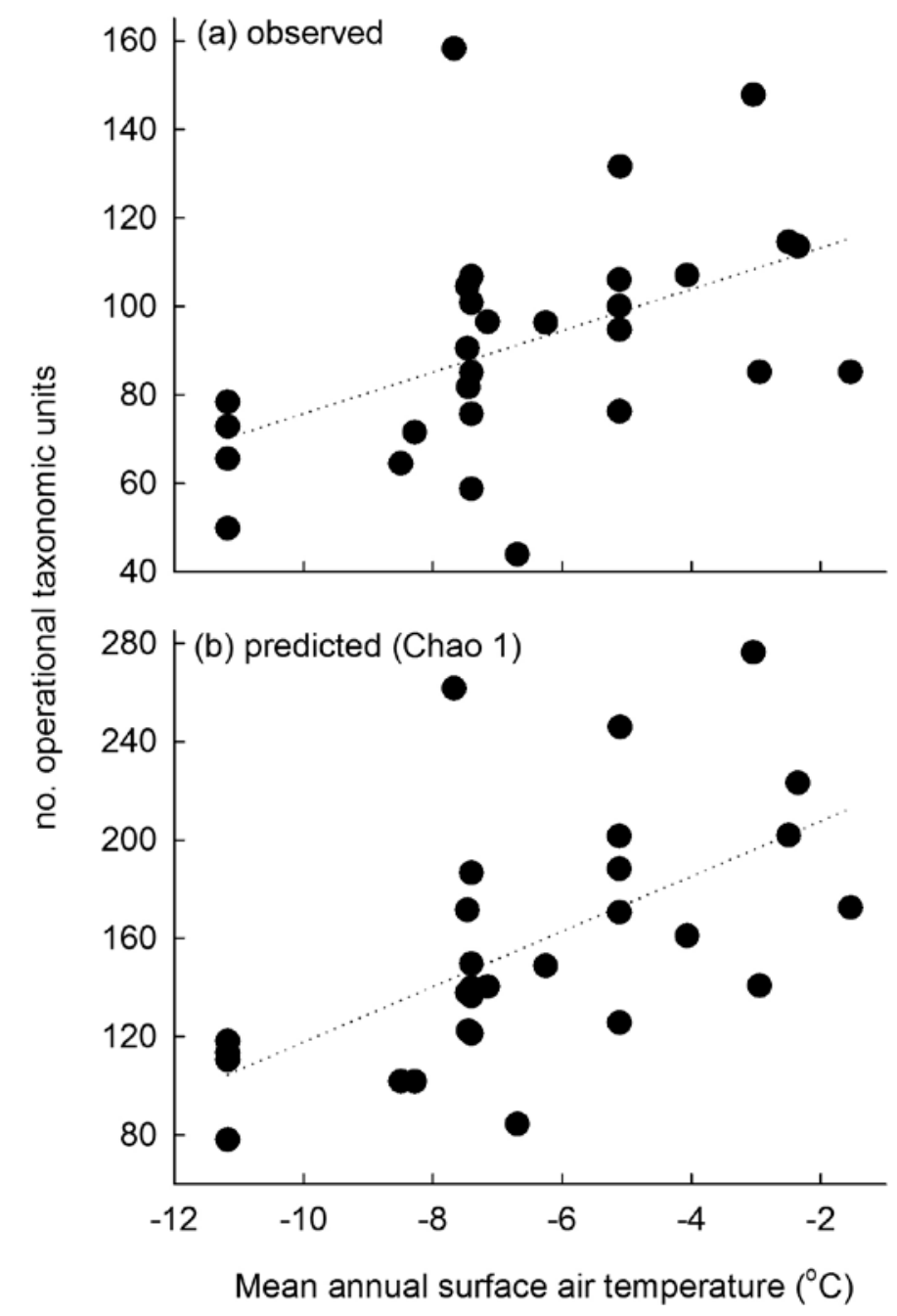

Figure 2 | The influence of mean annual surface air temperature on the numbers of soil fungal taxa along the climatic gradient. Data shown are the numbers of (a) observed and (b) predicted fungal taxa recorded in the 29 soils as a function of mean annual surface air temperature. Taxa were grouped at $97 \%$ similarity. The numbers of observed and predicted operational taxonomic units in each soil are shown in Supplementary Table S1. 

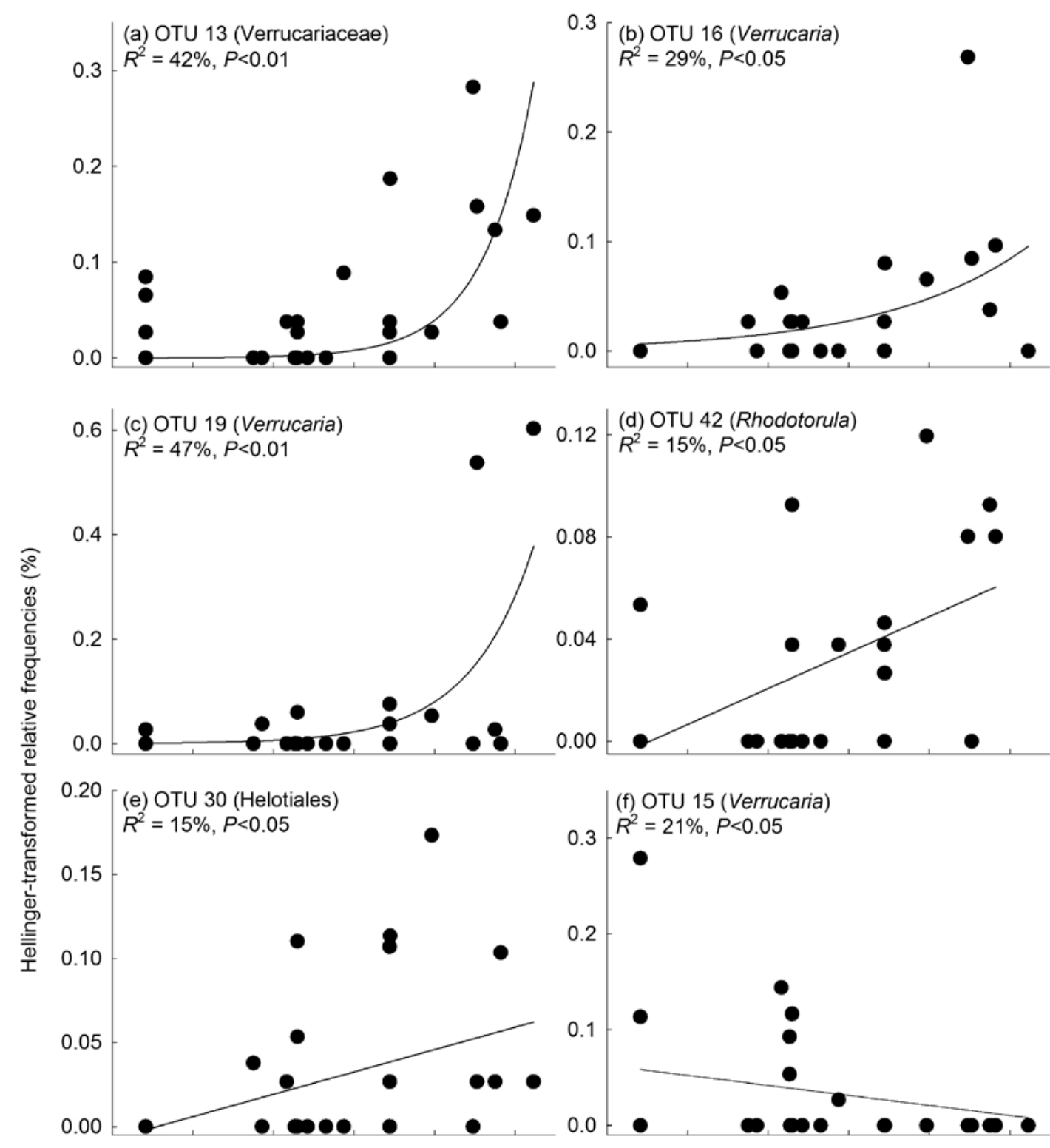

$0.12 \mid \begin{aligned} & \text { (d) OTU } 42 \text { (Rhodotorula) } \\ & R^{2}=15 \%, P<0.05\end{aligned}$
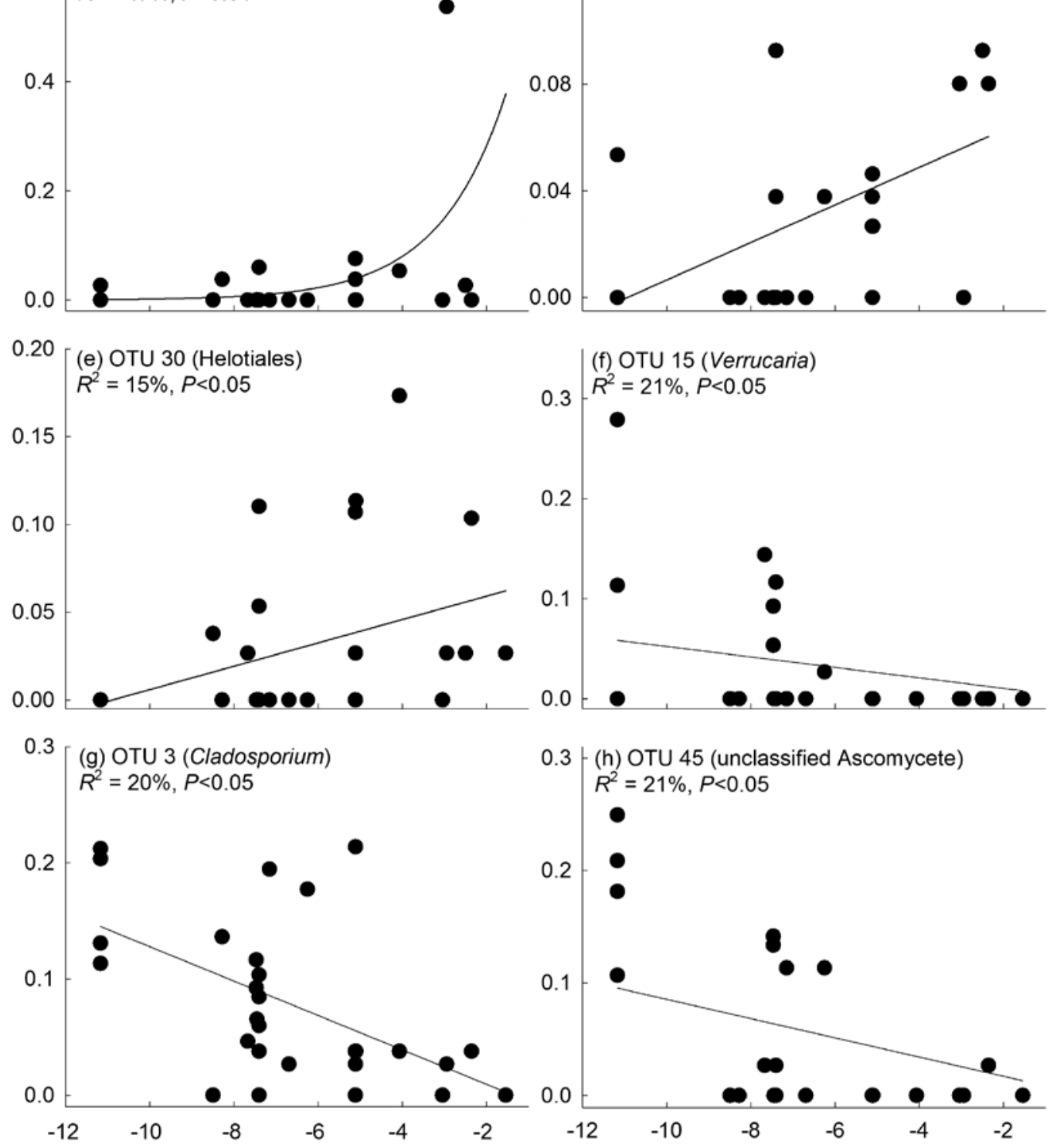

Mean annual surface air temperature $\left({ }^{\circ} \mathrm{C}\right)$

Figure 3 | The influence of mean annual surface air temperature on the frequencies of eight fungal taxa. Lines of best fit are either linear or polynomial functions. Note that $x$-axes are all identically scaled. 


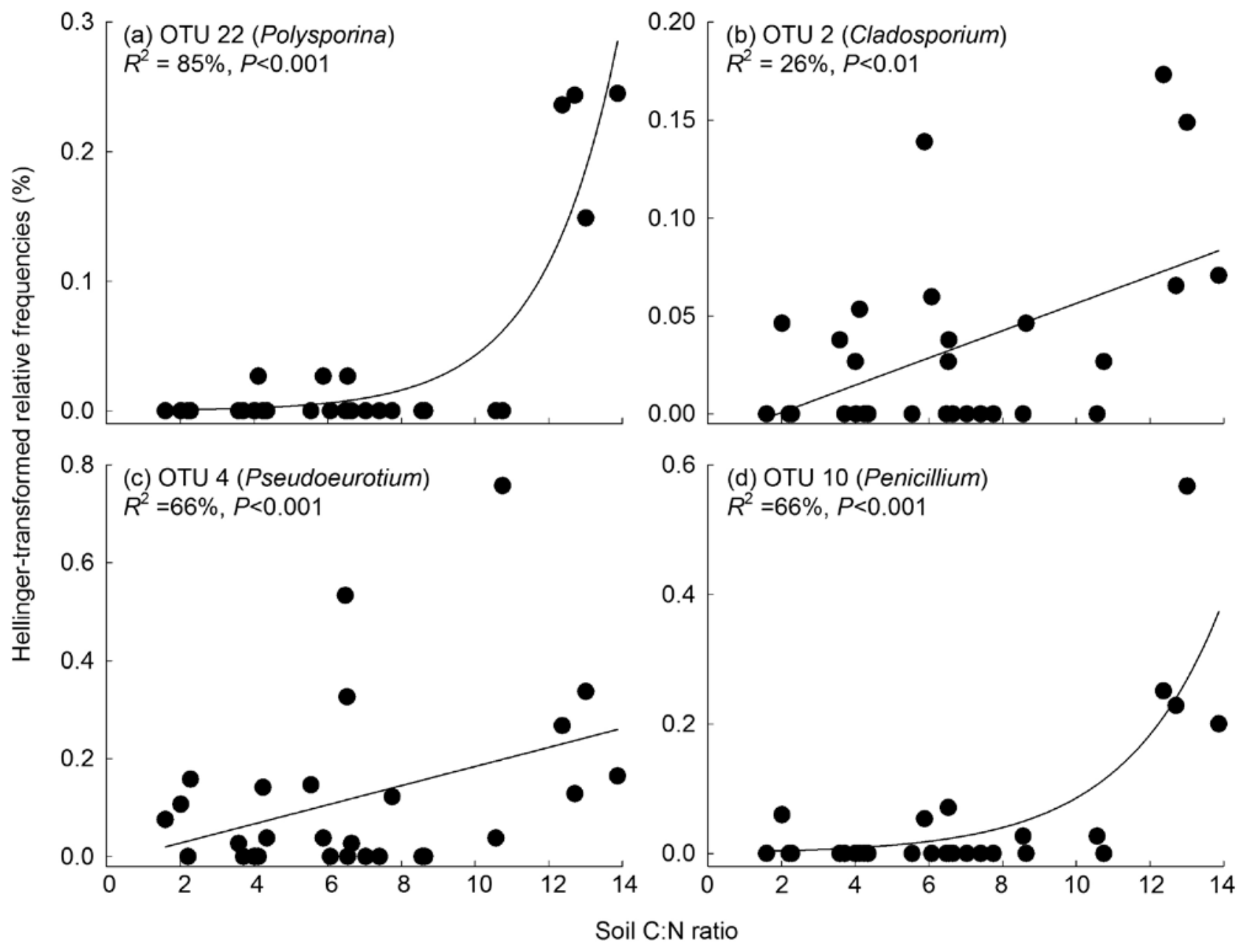

Figure 4 | The influence of soil C:N ratio on the frequencies of four fungal taxa. Lines of best fit are either linear or polynomial functions. Note that $x$-axes are all identically scaled. 


\section{Methods}

Soil sampling. To eliminate any effects of the presence of plants on soil fungal diversity, we sampled only soils without plant cover from along the climatic gradient. The uppermost five centimetres of soil was collected in $50 \mathrm{ml} \mathrm{DNA/RNAase-treated} \mathrm{plastic} \mathrm{tubes} \mathrm{(30} \mathrm{mm} \mathrm{diam.)} \mathrm{from} \mathrm{each} \mathrm{of} \mathrm{five} \mathrm{locations}$ at each site and was bulked. The soil was then immediately snap-frozen by immersion in a mixture of dry ice and ethanol $\left(\mathrm{C} .-80^{\circ} \mathrm{C}\right)$. Samples were maintained at $-80^{\circ} \mathrm{C}$ from the time of sampling until they were processed.

Air temperature data. The inaccessible nature of most of the sites studied precluded the measurement of soil temperature, and so mean annual surface air temperature (MASAT) data, derived from the Regional Atmospheric Climate Model over Antarctica ${ }^{18}$, gridded at a horizontal resolution of $55 \times 55 \mathrm{~km}$, were used as predictors of soil fungal diversity. MASAT values for the year 2007 in the grids in which each of the sampling sites occurred were used in statistical analyses (see below).

DNA extraction, PCR amplification and 454 pyrosequencing. Total DNA was extracted under sterile conditions from $10 \mathrm{~g}$ of soil using a PowerMax ${ }^{\circledR}$ Soil DNA isolation kit (MO BIO Laboratories, Inc., Carlsbad, CA, USA) as per the manufacturer's instructions. The internal transcribed spacer 2 (ITS2) region of the ribosomal RNA encoding genes was amplified by polymerase chain reaction (PCR) using the primers gITS7 (5' GTGARTCATCGARTCTTTG ${ }^{27}$ ) and ITS4 (5' TCCTCCGCTTATTGATATGC ${ }^{28}$ ), which target sites in the $5.8 \mathrm{~S}$ gene and ribosomal large subunit, respectively. The gITS7 primer was 5'-labelled with the 454 FLX sequencing primer adapter B sequence and the ITS4 primer was 5'-labelled with a sample specific barcode sequence and the 454 FLX sequencing primer adapter A sequence. PCRs were performed in duplicate $50 \mu \mathrm{l}$ reactions, each containing 5 ng template DNA, 1X Phusion ${ }^{\circledR}$ High Fidelity PCR Buffer (New England Biolabs Inc.), 0.2 $\mathrm{mM}$ of each of the dNTPs (Invitrogen), $0.3 \mu \mathrm{M}$ of the ITS4 primer, $0.5 \mu \mathrm{M}$ of the gITS7 primer, and $1 \mathrm{U}$ of $1 X$ Phusion $^{\circledR}$ High Fidelity DNA Polymerase (New England Biolabs Inc.). Thermocycling conditions were as follows: $98^{\circ} \mathrm{C}$ for $30 \mathrm{~s}, 35$ cycles of $98^{\circ} \mathrm{C}$ for $10 \mathrm{~s}, 56{ }^{\circ} \mathrm{C}$ for $30 \mathrm{~s}, 72{ }^{\circ} \mathrm{C}$ for $15 \mathrm{~s}$ and a final extension at $72{ }^{\circ} \mathrm{C}$ for $7 \mathrm{~min}$. Negative controls, consisting of sterile water in place of template DNA, did not yield amplicons. Amplicons were purified using a Wizard® SV Gel and PCR Clean-Up System (Promega), quantified with a Qubit fluorometer with a Quant-iT dsDNA HF assay kit and then $72 \mathrm{ng}$ of each sample was pooled. The pooled sample was purified again using a QIAquick PCR Purification Kit (Qiagen), and then sent to Macrogen (Seoul, Korea) for 454 pyrosequencing ${ }^{29}$.

Processing of sequence data. Sequences were quality filtered and dereplicated using the QIIME script split_libraries.py with the homopolymer filter deactivated ${ }^{30}$. Homopolymer errors were corrected using Acacia v. $1.48^{31}$ and fungal ITS2 sequences were then extracted using ITSX v. 1.0.9 ${ }^{32}$ and checked for chimeras against ITS2 sequences in UNITE v. $6^{33}$ using UCHIME v. 3.0.617 $7^{34}$. At least 1,435 non-chimeric quality-filtered ITS2 sequences were derived from each soil sample. The sequences were clustered at $97 \%$ similarity using UCLUST v. 1.2.22. UNITE v. $6^{35}$ taxonomy was 
assigned to representative OTU sequences using BLAST v. 2.2.30. Tables containing the abundances of different OTUs and their taxonomic assignments in each sample were generated and the number of reads was rarefied to 1400 per sample. The mean number of observed OTUs and the estimated total number of OTUs (Chao 1) were calculated using QIIME.

Soil physicochemistry. Soil pH and electrical conductivity were measured in 1:2.5 and 1:5 soil:water (vol:vol) slurries, respectively. Total nitrogen and organic carbon concentrations were determined using an Exeter Analytical CE440 Elemental Analyzer (EAI, Coventry, UK) following desiccation at $105^{\circ} \mathrm{C}$ and treatment with $\mathrm{HCl}$ to remove inorganic carbon. Concentrations of $\mathrm{Ca}, \mathrm{Cu}, \mathrm{Fe}, \mathrm{K}, \mathrm{Mg}, \mathrm{Mn}$, $\mathrm{Ni}, \mathrm{P}$ and $\mathrm{Zn}$ ( $\mathrm{mg} \mathrm{kg}^{-1}$ dry soil) were determined using ICP-MS following reverse aqua regia digests. Water extractable $\mathrm{PO}_{4}{ }^{3-}, \mathrm{SO}_{4}{ }^{2-}$ and $\mathrm{Cl}^{-}$concentrations ( $\mathrm{mg} \mathrm{kg}^{-1}$ dry soil) were determined using Dionex ion chromatography. Soil $\mathrm{NH}_{4}{ }^{+}-\mathrm{N}, \mathrm{NO}_{3}{ }^{-}-\mathrm{N} / \mathrm{NO}_{2}-\mathrm{N}$ and dissolved organic carbon (DOC) concentrations ( $\mathrm{mg} \mathrm{kg}^{-1}$ dry soil) were determined in $1 \mathrm{M} \mathrm{KCl}$ (1:4 dry soil equivalent to solution ratio) followed by automated flow injection analysis (Skalar Analytical B.V., The Netherlands). The moisture content of each soil sample was determined gravimetrically. All analyses were based on soil passed through a 4 $\mathrm{mm}$ sieve.

Statistical analyses. The influence of MASAT and soil physicochemical parameters on changes in the composition of soil fungal communities between sites (beta diversity) was assessed using Redundancy Analysis (RDA) with Monte Carlo permutation tests to assess the significance of the constraints. Parameters were chosen for inclusion in the final RDA model by forward selection based on Akaike's Information Criterion (AIC). When the inclusion of a new parameter led to other terms becoming insignificant $(P>0.05)$, it was dropped, leaving the final minimally adequate model. All models were built for Hellinger transformed OTU abundances. All analyses were implemented in R. Associations between soil fungal diversity, latitude, MASAT and soil physicochemical parameters were examined using polynomial and multivariate regressions. For the univariate models we adopted a principle of parsimony, accepting the model with the least number of coefficients commensurate with the greatest amount of variation ( $R^{2}$ value) explained. Since some of the covariates were themselves related and causally linked (e.g. latitude and MASAT), we hypothesised that each could have both direct effects on the response variables and indirect effects through their direct effects on other predictors. For this reason we used structural equation modelling (SEM) to investigate the direct and indirect effects of latitude, MASAT and soil physicochemical parameters on soil fungal richness. Based on the output from our univariate models, we created a full SEM model to test the hypotheses that latitude directly affected MASAT, soil C:N ratio and fungal richness, that MASAT directly affected fungal richness, that soil $\mathrm{K}$ concentration directly affected fungal richness and that MASAT directly affected soil C: $\mathrm{N}$ ratio. The hypothetical full model was then challenged with the data and goodness of fit assessed using Chi-squared tests and root mean square error of approximation (RMSEA) values. Variables and associated relationships were then removed progressively if they were not significant. The Chi-squared goodness of fit tested the difference between the hypothetical model pathway and 
the observed data. RMSEA values of $<0.05$ for the model were considered a good fit to the data. SEM analyses were performed in Amos version 22 (SPSS Software, Chicago).

\section{References}

27. Ihrmark, K. et al. New primers to amplify the fungal ITS2 region - evaluation by 454-sequencing of artificial and natural communities. FEMS Microbiol. Ecol. 82, 666-677 (2012).

28. White, T. J., Bruns, T. D., Lee, S. B. \& Taylor, J. W. in PCR Protocols: a guide to methods and applications (eds Innis, M. A., Gelfand, H., Sninsky, J. S. \& White, T.J.) 315-321 (Academic Press, Berkeley, 1990).

29. Margulies, M. et al. Genome sequencing in microfabricated high-density picolitre reactors. Nature 437, 376-380 (2005).

30. Caporaso, J. G. et al. QIIME allows analysis of high-throughput community sequencing data. Nat. Methods 7, 335-336 (2010).

31. Bragg, L., Stone, G., Imelfort, M., Hugenholtz, P. \& Tyson, G. W. Fast, accurate error-correction of amplicon pyrosequences using Acacia. Nat. Methods 9, 425-426 (2012).

32. Bengtsson-Palme, J. et al. ITSx: Improved software detection and extraction of ITS1 and ITS2 from ribosomal ITS sequences of fungi and other eukaryotes for use in environmental sequencing. Methods Ecol. Evol. 4, 914-919 (2013).

33. Nilsson, R. H. et al. A comprehensive, automatically updated fungal ITS sequence dataset for reference-based chimera control in environmental sequencing efforts. Microbes Environ. 30 , 145-150 (2015).

34. Edgar, R. C. Search and clustering orders of magnitude faster than BLAST. Bioinformatics 26, 2460-2461 (2010).

35. Kõljalg, U. et al. Towards a unified paradigm for sequence-based identification of fungi. Molec. Ecol. 22, 5271-5277 (2013). 


\section{Supplementary Information}

Contents:

Supplementary Table S1 | Site locations and alpha diversity metrics

Supplementary Table S2 | Univariate linear regression data

Supplementary Table S3 | Identities of OTUs

Supplementary Figure S1 | Images of sampling sites

Supplementary Figure S2 | Structural equation model

Supplementary Figure S3 | Heatmap of the 50 most abundant OTUs 
Supplementary Table S1 | Site locations and alpha diversity metrics.

\begin{tabular}{|c|c|c|c|c|c|}
\hline \multirow{2}{*}{\multicolumn{2}{|c|}{ Sampling site }} & \multirow{3}{*}{$\begin{array}{l}\text { Latitude and longitude } \\
71.878^{\circ} \mathrm{S}, 68.248^{\circ} \mathrm{W}\end{array}$} & \multirow{2}{*}{$\begin{array}{c}\text { Altitude } \\
\text { (metres } \\
\text { a.s.I.) }\end{array}$} & \multicolumn{2}{|c|}{ No. OTUs } \\
\hline & & & & \multirow{2}{*}{$\begin{array}{c}\text { Observed }^{*} \\
72.85\end{array}$} & \multirow{2}{*}{$\begin{array}{c}\begin{array}{r}\text { Predicted } \\
(\text { Chao1)* }\end{array} \\
110.41\end{array}$} \\
\hline 1 & Mars Oasis, Alexander Island & & 15 & & \\
\hline 2 & Mars Oasis, Alexander Island & $71.878^{\circ} \mathrm{S}, 68.248^{\circ} \mathrm{W}$ & 15 & 65.55 & 118.10 \\
\hline 3 & Mars Oasis, Alexander Island & $71.878^{\circ} \mathrm{S}, 68.248^{\circ} \mathrm{W}$ & 15 & 49.85 & 78.02 \\
\hline 4 & Mars Oasis, Alexander Island & $71.878^{\circ} \mathrm{S}, 68.248^{\circ} \mathrm{W}$ & 15 & 78.40 & 113.36 \\
\hline 5 & Mount Holt, Alexander Island & $69.408^{\circ} \mathrm{S}, 71.665^{\circ} \mathrm{W}$ & 70 & 85.05 & 121.22 \\
\hline 6 & $\begin{array}{l}\text { Hopkins Ridge, Alexander } \\
\text { Island }\end{array}$ & $69.366^{\circ} \mathrm{S}, 71.842^{\circ} \mathrm{W}$ & 62 & 106.80 & 136.48 \\
\hline 7 & $\begin{array}{l}\text { Hopkins Ridge, Alexander } \\
\text { Island }\end{array}$ & $69.366^{\circ} \mathrm{S}, 71.844^{\circ} \mathrm{W}$ & 62 & 58.75 & 139.73 \\
\hline 8 & $\begin{array}{l}\text { Hopkins Ridge, Alexander } \\
\text { Island }\end{array}$ & $69.367^{\circ} \mathrm{S}, 71.844^{\circ} \mathrm{W}$ & 66 & 75.65 & 186.62 \\
\hline 9 & $\begin{array}{l}\text { Hopkins Ridge, Alexander } \\
\text { Island }\end{array}$ & $69.368^{\circ} \mathrm{S}, 71.844^{\circ} \mathrm{W}$ & 501 & 100.75 & 149.46 \\
\hline 10 & Jenny Island & $67.731^{\circ} \mathrm{S}, 68.365^{\circ} \mathrm{W}$ & 12 & 100.05 & 188.23 \\
\hline 11 & Lagoon Island & $67.594^{\circ} \mathrm{S}, 68.247^{\circ} \mathrm{W}$ & 20 & 106.00 & 201.55 \\
\hline 12 & Rothera Point, Adelaide island & $67.568^{\circ} \mathrm{S}, 68.114^{\circ} \mathrm{W}$ & 6 & 43.95 & 84.36 \\
\hline 13 & Blaiklock Island & $67.543^{\circ} \mathrm{S}, 67.198^{\circ} \mathrm{W}$ & 7 & 64.50 & 101.72 \\
\hline 14 & Detaille Island & $66.790^{\circ} \mathrm{S}, 66.869^{\circ} \mathrm{W}$ & 21 & 96.30 & 148.67 \\
\hline 15 & $\begin{array}{l}\text { Cape Evenson, Antarctic } \\
\text { Peninsula }\end{array}$ & $66.145^{\circ} \mathrm{S}, 65.717^{\circ} \mathrm{W}$ & 59 & 81.75 & 122.21 \\
\hline 16 & $\begin{array}{l}\text { Yelcho Station }(\mathrm{CHL}) \\
\text { Wiencke Island }\end{array}$ & $64.894^{\circ} \mathrm{S}, 63.553^{\circ} \mathrm{W}$ & 6 & 94.70 & 170.42 \\
\hline 17 & Port Lockroy, Goudier Island & $64.817^{\circ} \mathrm{S}, 63.483^{\circ} \mathrm{W}$ & 10 & 76.25 & 125.57 \\
\hline 18 & $\begin{array}{l}\text { Marambio Station (ARG), } \\
\text { Seymour Island }\end{array}$ & $64.236^{\circ} \mathrm{S}, 56.626^{\circ} \mathrm{W}$ & 160 & 71.55 & 101.65 \\
\hline 19 & Alectoria Island & $63.977^{\circ} \mathrm{S}, 58.640^{\circ} \mathrm{W}$ & 50 & 104.50 & 171.40 \\
\hline 20 & Alectoria Island & $63.977^{\circ} \mathrm{S}, 58.640^{\circ} \mathrm{W}$ & 25 & 90.50 & 137.69 \\
\hline 21 & Spert Island & $63.844^{\circ} \mathrm{S}, 60.945^{\circ} \mathrm{W}$ & 92 & 131.60 & 245.89 \\
\hline 22 & $\begin{array}{l}\text { Cape Lachman, James Ross } \\
\text { Island }\end{array}$ & $63.782^{\circ} \mathrm{S}, 57.783^{\circ} \mathrm{W}$ & 81 & 158.20 & 261.64 \\
\hline 23 & nunatak, unnamed & $63.559^{\circ} \mathrm{S}, 57.823^{\circ} \mathrm{W}$ & 617 & 96.50 & 140.20 \\
\hline 24 & Whalers Bay, Deception Island & $62.977^{\circ} \mathrm{S}, 60.552^{\circ} \mathrm{W}$ & 91 & 114.55 & 201.86 \\
\hline 25 & $\begin{array}{l}\text { South Beaches, Byers } \\
\text { Peninsula, Livingston Island }\end{array}$ & $62.655^{\circ} \mathrm{S}, 61.090^{\circ} \mathrm{W}$ & 64 & 85.15 & 172.41 \\
\hline
\end{tabular}




\begin{tabular}{|c|c|c|c|c|c|}
\hline 26 & Edwards Point, Robert Island & $62.460^{\circ} \mathrm{S}, 59.509^{\circ} \mathrm{W}$ & 26 & 147.80 & 276.18 \\
\hline 27 & Orión Point, Greenwich Island & $62.447^{\circ} \mathrm{S}, 59.736^{\circ} \mathrm{W}$ & 13 & 113.55 & 223.13 \\
\hline 28 & $\begin{array}{l}\text { Keller Peninsula, King George } \\
\text { Island }\end{array}$ & $62.086^{\circ} \mathrm{S}, 58.399^{\circ} \mathrm{W}$ & 65 & 85.15 & 140.61 \\
\hline 29 & Wynn Knolls, Signy Island & $60.701^{\circ} \mathrm{S}, 45.661^{\circ} \mathrm{W}$ & 199 & 107.00 & 160.90 \\
\hline
\end{tabular}

*Data are based on sequences clustered at $97 \%$ similarity and rarefied to 1,400 reads per soil. Abbreviations: $\mathrm{CHL}$, Chile; ARG, Argentina 
Supplementary Table $S 2 \mid R^{2}$ and $P$ values from univariate linear regressions between latitude and mean annual surface air temperature, altitude and soil physicochemical parameters.

\begin{tabular}{|c|c|c|}
\hline Parameter & $R^{2}$ value (\%) & $P$ value \\
\hline $\operatorname{MASAT}^{*}\left({ }^{\circ} \mathrm{C}\right)$ & 62.30 & $<0.001^{\star \star \star}$ \\
\hline Altitude (metres a.s.I.) & 2.5 & 0.413 \\
\hline $\mathrm{pH}$ value & 0.01 & 0.966 \\
\hline Electrical conductivity $\left(\mu \mathrm{S} \mathrm{cm}^{-1}\right)$ & 1.42 & 0.539 \\
\hline Organic $\mathrm{C}$ concentration ( $\mathrm{mg} \mathrm{kg}^{-1}$ dry soil) & 0.64 & 0.679 \\
\hline $\mathrm{N}$ concentration ( $\mathrm{mg} \mathrm{kg}^{-1}$ dry soil) & 0.29 & 0.780 \\
\hline $\mathrm{C}: \mathrm{N}$ ratio & 32.60 & $0.001^{\star \star}$ \\
\hline Ca concentration ( $\mathrm{mg} \mathrm{kg}^{-1}$ dry soil) & 0.40 & 0.744 \\
\hline Cu concentration (mg kg${ }^{-1}$ dry soil) & 3.14 & 0.358 \\
\hline Fe concentration ( $\mathrm{mg} \mathrm{kg}^{-1}$ dry soil) & 6.17 & 0.194 \\
\hline K concentration ( $\mathrm{mg} \mathrm{kg}^{-1}$ dry soil) & 0.16 & 0.835 \\
\hline Mg concentration ( $\mathrm{mg} \mathrm{kg}^{-1}$ dry soil) & 10.49 & 0.099 \\
\hline Mn concentration ( $\mathrm{mg} \mathrm{kg}^{-1}$ dry soil) & 2.97 & 0.371 \\
\hline Ni concentration ( $\mathrm{mg} \mathrm{kg}^{-1}$ dry soil) & 7.20 & 0.176 \\
\hline P concentration ( $\mathrm{mg} \mathrm{kg}^{-1}$ dry soil) & 0.31 & 0.775 \\
\hline Zn concentration ( $\mathrm{mg} \mathrm{kg}^{-1}$ dry soil) & 1.39 & 0.543 \\
\hline Dissolved organic $\mathrm{C}$ concentration ( $\mathrm{mg} \mathrm{kg}^{-1}$ dry soil) & 0.73 & 0.658 \\
\hline Dissolved $\mathrm{NO}_{3}{ }^{-}-\mathrm{N} / \mathrm{NO}_{2}{ }^{-}-\mathrm{N}$ concentration ( $\mathrm{mg} \mathrm{kg}^{-1}$ dry soil) & 0.01 & 0.953 \\
\hline Dissolved $\mathrm{NH}_{4}{ }^{+}-\mathrm{N}$ concentration ( $\mathrm{mg} \mathrm{kg}^{-1}$ dry soil) & 0.10 & 0.869 \\
\hline Dissolved $\mathrm{SO}_{4}{ }^{2-}$ concentration ( $\mathrm{mg} \mathrm{kg}^{-1}$ dry soil) & 1.37 & 0.545 \\
\hline Dissolved $\mathrm{PO}_{4}{ }^{3-}$ concentration ( $\mathrm{mg} \mathrm{kg}^{-1}$ dry soil) & 0.25 & 0.796 \\
\hline Dissolved $\mathrm{Cl}^{-}$concentration ( $\mathrm{mg} \mathrm{kg}^{-1}$ dry soil) & 1.22 & 0.569 \\
\hline
\end{tabular}

${ }^{*}$ mean annual surface air temperature. Error degrees of freedom in analyses were 26-28. Note that four outlying points were removed from the data matrix (consisting of 667 observations) prior to analyses. 
Supplementary Table S3 | Closest BLAST hits of the top 50 operational taxonomic units* and their associated UNITE species hypotheses.

\begin{tabular}{|c|c|c|c|c|}
\hline \multirow[b]{2}{*}{ OTU } & \multirow[b]{2}{*}{ Taxonomic assignment } & \multirow{2}{*}{$\begin{array}{c}\text { Closest UNITE } \\
\text { species hypothesis }\end{array}$} & \multicolumn{2}{|c|}{ Closest BLAST hit } \\
\hline & & & NCBI accession no. & Geographical origin \\
\hline 1 & Megasporaceae sp. & SH038307.06FU & FR682345 & Finland \\
\hline 2 & Davidiellaceae; Cladosporium sp. & SH196750.06FU & KJ598781 & China \\
\hline 3 & Davidiellaceae; Cladosporium sp. & SH196750.06FU & KJ411576 & India \\
\hline 4 & Pseudoeurotiaceae; Pseudoeurotium sp. & SH209178.06FU & HM589327 & Antarctic Peninsula \\
\hline 5 & Pseudoeurotiaceae; Pseudogymnoascus sp. & SH236509.06FU & KC457091 & King George Island, Antarctica \\
\hline 6 & Eurotiomycetes sp. & SH030591.06FU & HQ634132 & Antarctica \\
\hline 7 & Eurotiomycetes sp. & SH030588.06FU & KC965283 & Canadian Arctic \\
\hline 8 & Herpotrichiellaceae; Capronia sp. & SH209735.06FU & FR682430 & Finland \\
\hline 9 & Herpotrichiellaceae sp. & SH228285.06FU & KF636404 & Léonie Island, Antarctica \\
\hline 10 & Trichocomaceae; Penicillium sp. & SH231333.06FU & KF597019 & Himalayas \\
\hline 11 & Verrucariaceae sp. & SH022709.06FU & KC966268 & Alaskan Arctic \\
\hline 12 & Verrucariaceae sp. & SH024484.06FU & KF297206 & Canadian Arctic \\
\hline 13 & Verrucariaceae sp. & SH221269.06FU & KC965575 & Canadian Arctic \\
\hline 14 & Verrucariaceae; Verrucaria sp. & SH022729.06FU & FJ667941 & United Kingdom \\
\hline 15 & Verrucariaceae; Verrucaria sp. & SH022737.06FU & KF296796 & Canadian Arctic \\
\hline 16 & Verrucariaceae; Verrucaria sp. & SH197325.06FU & FJ667941 & United Kingdom \\
\hline 17 & Verrucariaceae; Verrucaria sp. & SH022766.06FU & KC965347 & Canadian Arctic \\
\hline 18 & Verrucariaceae; Verrucaria sp. & SH221271.06FU & FJ664852 & United Kingdom \\
\hline 19 & Verrucariaceae; Verrucaria sp. & SH022730.06FU & FJ664870 & United Kingdom \\
\hline 20 & Verrucariaceae; Verrucaria sp. & SH022730.06FU & FJ664872 & Iceland \\
\hline 21 & Acarosporaceae; Acarospora sp. & SH228160.06FU & EU870668 & United Kingdom \\
\hline 22 & Acarosporaceae; Polysporina sp. & SH032519.06FU & JX036093 & Dry Valleys, Antarctica \\
\hline 23 & Ramalinaceae; Waynea sp. & SH026019.06FU & AF282099 & USA \\
\hline
\end{tabular}




\begin{tabular}{|c|c|}
\hline 24 & Lecideaceae; Lecidea sp. \\
\hline 25 & Physciaceae; Buellia sp. \\
\hline 26 & Leotiomycetes sp. \\
\hline 27 & Helotiales sp. \\
\hline 28 & Helotiales sp. \\
\hline 29 & Helotiales sp. \\
\hline 30 & Helotiales sp. \\
\hline 31 & Helotiales sp. \\
\hline 32 & Leotiaceae; Alatospora sp. \\
\hline 33 & Pseudeurotiaceae sp. \\
\hline 34 & Pseudeurotiaceae; Leuconeurospora sp. \\
\hline 35 & Thelebolaceae; Antarctomyces sp. \\
\hline 36 & Thelebolaceae; Thelebolus sp. \\
\hline 37 & Pezizomycetes sp. \\
\hline 38 & Nectriaceae; Fusarium sp. \\
\hline 39 & Ascomycota sp. \\
\hline 40 & Ascomycota sp. \\
\hline 41 & Ascomycota sp. \\
\hline 42 & Kriegeriaceae; Rhodotorula sp. \\
\hline 43 & Kriegeriaceae; Rhodotorula sp. \\
\hline 44 & Basidiomycota sp. \\
\hline 45 & Unidentified \\
\hline 46 & Unidentified \\
\hline 47 & Unidentified \\
\hline 48 & Mortierellaceae; Mortierella sp. \\
\hline & Mortierellaceae; Mortierella sp. \\
\hline
\end{tabular}

\begin{tabular}{lc} 
SH224611.06FU & JX036045 \\
SH028904.06FU & HQ650628 \\
SH018537.06FU & GU067676 \\
SH216429.06FU & KC785555 \\
SH220881.06FU & JX001631 \\
SH207339.06FU & JX852366 \\
SH197325.06FU & EU292671 \\
SH220883.06FU & X88771 \\
SH207345.06FU & KF617795 \\
SH209227.06FU & KC455895 \\
SH209227.06FU & JQ857041 \\
SH222305.06FU & KC514843 \\
SH195163.06FU & KC457177 \\
SH194645.06FU & EF635708 \\
SH217297.06FU & KJ655442 \\
SH021267.06FU & KC965667 \\
SH021267.06FU & KC965667 \\
m.d. & KJ523042 \\
SH216408.06FU & JQ857032 \\
SH228918.06FU & KC206490 \\
SH028275.06FU & KC966210 \\
SH241742.06FU & EF635742 \\
SH228811.06FU & KC966059 \\
SH023732.06FU & KC966243 \\
SH217216.06FU & JQ6670951 \\
SH221068.06FU & HM589301 \\
& \\
\hline &
\end{tabular}

Dry Valleys, Antarctica USA

Austria

Mount Erebus, Antarctica Tibetan Plateau

Ardley Island, Antarctica

Alaskan Arctic

Ötztal Alps, Austria

Alaskan Arctic

Mount Blanc, Italian Alps

King George Island, Antarctica

Deception Island, Antarctica

King George Island, Antarctica

Austrian Alps

China

Alaskan Arctic

Alaskan Arctic

Hawaii

King George Island, Antarctica

Lake Vostok, Antarctica

Alaskan Arctic

Austrian Alps

Canadian Arctic

Canadian Arctic

King George Island, Antarctica

Antarctic Peninsula 
*OTU numbers correspond to those shown in Supplementary Figure S3. 


\section{Supplementary Figures}
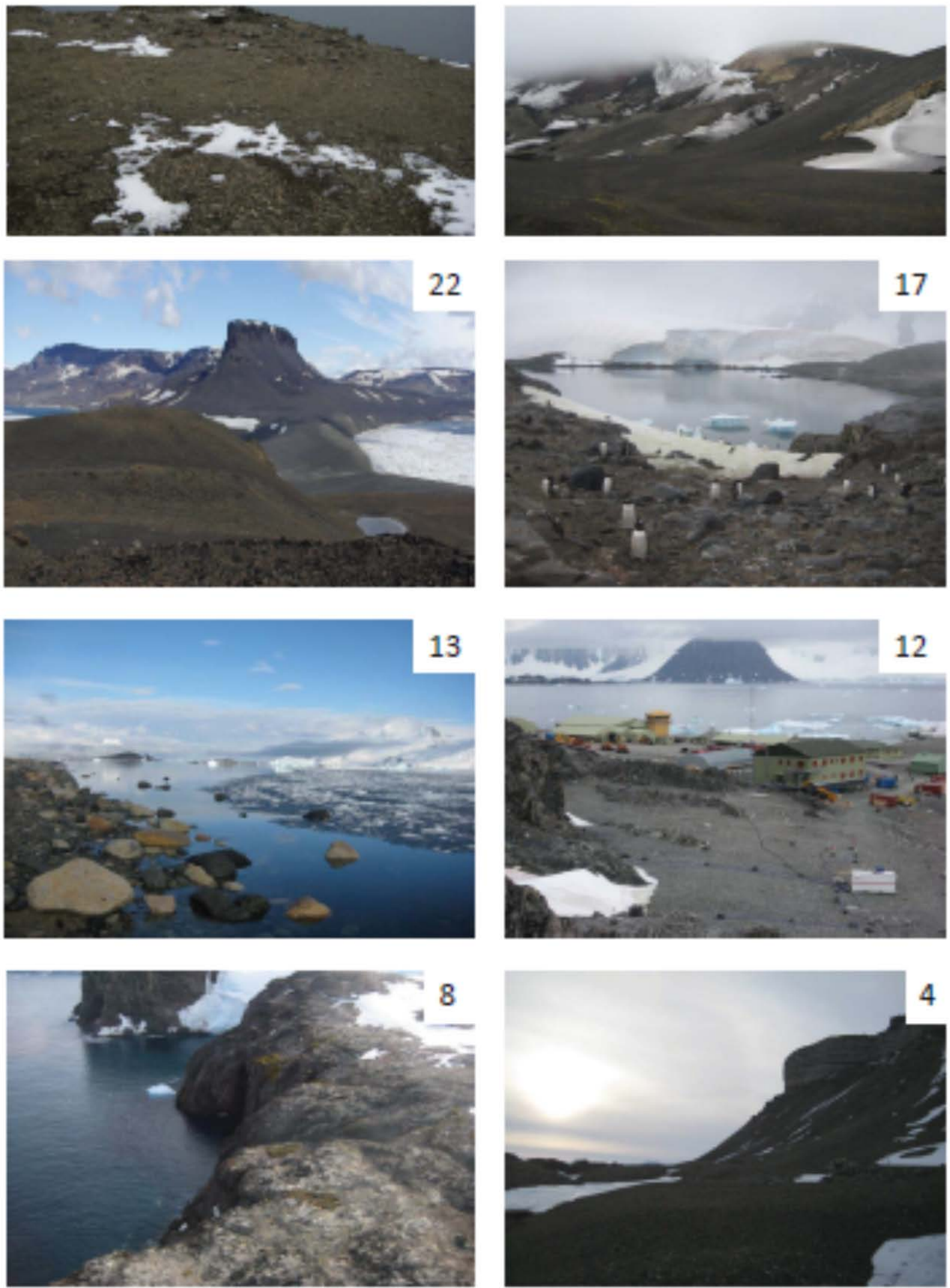

Supplementary Figure S1 | Images of eight of the sampling sites. The numbers correspond to the site numbers in Fig. 1 and Supplementary Table S1. 


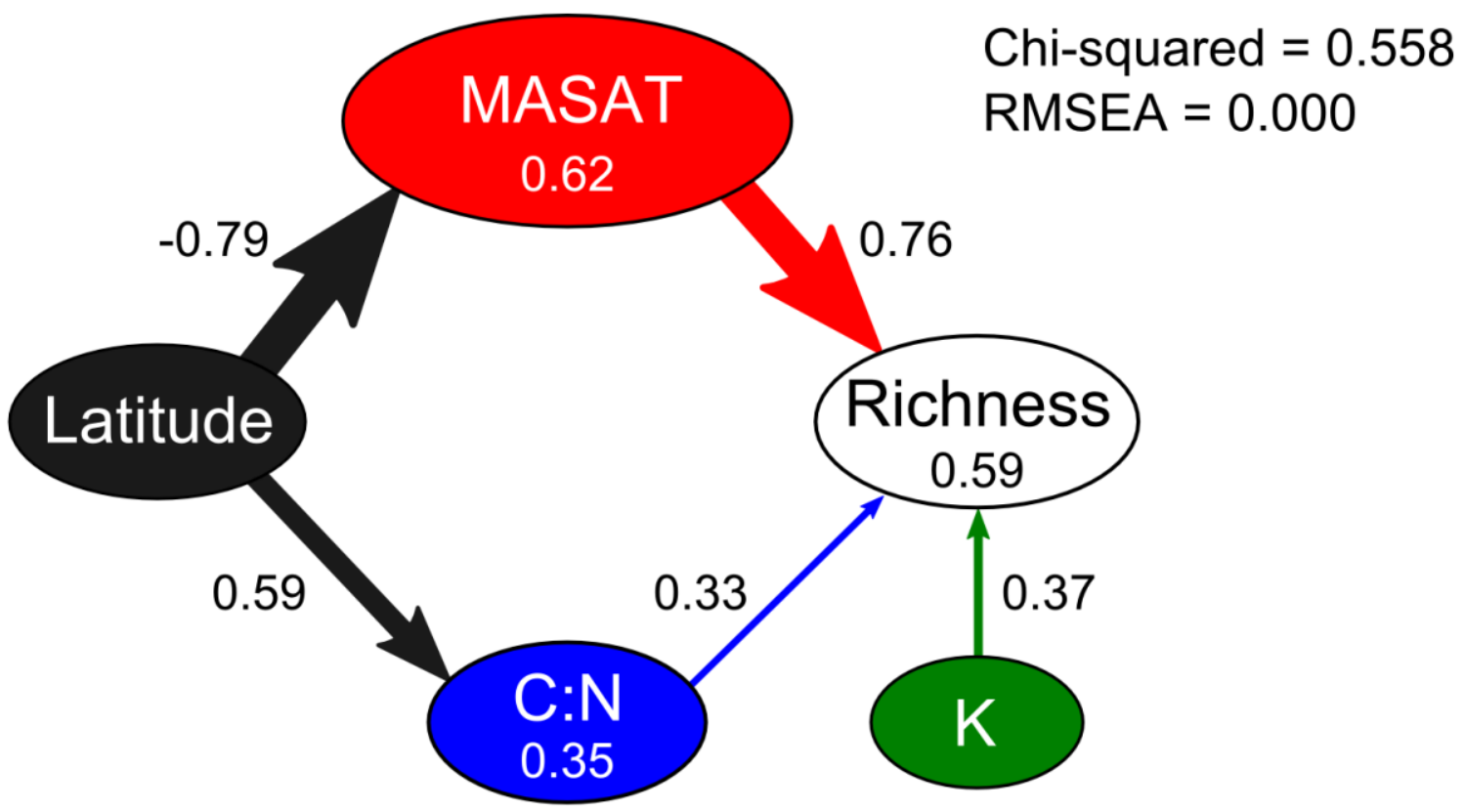

Supplementary Figure S2 | Structural equation model showing the influences of latitude, mean annual surface air temperature, soil $\mathrm{C}: \mathrm{N}$ ratio and soil potassium concentration on the richness of maritime Antarctic soil fungal communities. 


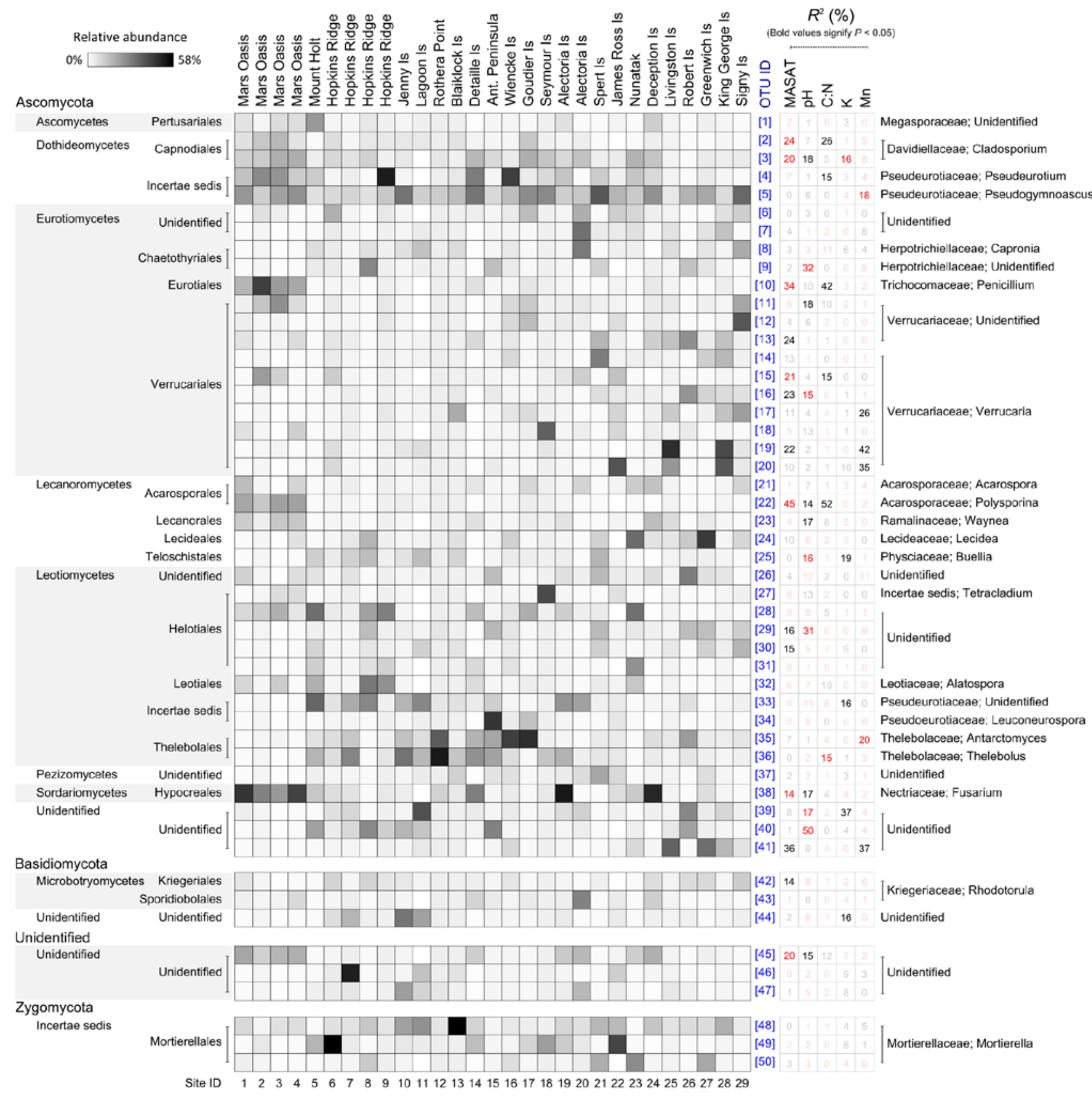

Supplementary Figure S3 | Heatmap showing the frequencies of the 50 most abundant taxa of soil fungi along the climatic gradient. $R^{2}$ values shown in black and red indicate positive and negative associations, respectively. UNITE species hypothesis accessions for each taxon are shown in Supplementary Table S3. 